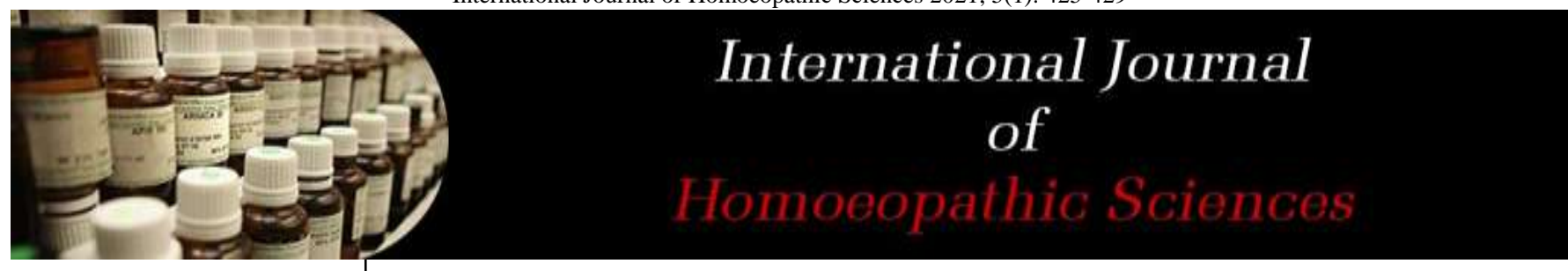

E-ISSN: $2616-4493$ www.homoeopathicjournal.com IJHS 2021; 5(1): 425-429

Received: 17-12-2020

Accepted: 19-01-2021

Dr. Tina Anand

Reader, Department

Pathology and Microbiology,

Homoeopathic Medical

College, Chandigarh

Punjab University,

Chandigarh, Punjab, India P-ISSN: 2616-4485

\section{Heel pain management at homoeopathic OPDs}

\section{Dr. Tina Anand}

DOI: $\underline{\text { https://doi.org/10.33545/26164485.2021.v5.i1g.347 }}$

\section{Abstract}

Heel pain is a common presenting complaint at homoeopathic OPDs. Majority of patients visiting suffer invariably from chronic heel pain and less often do patients with short history of heel pain come to homoeopaths. Though a very mild condition yet a frequent presentation that becomes challenging both for patient and the physician as in many cases it lingers on for long periods defying conservative treatments. It thus becomes imperative for every physician to have an insight into the most common causes, symptoms, investigations and differential diagnosis, conservative treatment along with Homoeopathic approach to such cases. A brief therapeutic Index has been prepared in the end of the article based on Murphy's Repertory for easy reference.

Keywords: Heel pain, homoeopathic therapeutics

\section{Introduction}

Heel is a padded cushion of fatty tissue around the heel bone (the calcaneus) which serves to protect the structures of the foot, including the calcaneus, muscles and ligaments. Pain in heel can result from below given causes.

\begin{tabular}{|c|c|}
\hline Category & Conditions \\
\hline Arthritic & $\begin{array}{c}\text { Gout, Rheumatoid Arthritis, seronegativearthropathy, primary and secondary } \\
\text { arthopathy }\end{array}$ \\
\hline Infectious & Diabetic ulcer, osteomyelitis, planter warts \\
\hline Mechanical & $\begin{array}{l}\text { Planter- planter fasciitis, heel spur, calcaneal stress fracture, medial or lateral } \\
\text { planter nerve entrapment, heel pad syndrome } \\
\text { Posterior- Achilles tendinopathy, Haglund Deformity, Sever's disease, } \\
\text { retrocalcaneal bursitis }\end{array}$ \\
\hline Neuropathic & Nerve entrapment, tarsal tunnel syndrome, neuroma \\
\hline Trauma & \\
\hline Tumor & Neuroma, Ewing's sarcoma \\
\hline
\end{tabular}

Of all the above given categories, mechanical causes are the most common. Amongst the mechanical causes the most frequently presenting conditions are those of Planter Fasciitis, Calcaneal Spur, Sever's disease followed by Heel pad syndrome, Achilles Tendinopathy, Haglund Deformity and Nerve entrapment.

\section{Groups at higher risk of developing heel pain}

Anyone can suffer from heel pain, but certain groups are at increased risk including:

- Obese

- Sportsperson-Athletes, Gymnasts.

- People doing high intensity exercises-Physically active people, joggers, runners

- People who have to be on their feet for long periods of time or have to run, jump on hard surfaces

Corresponding Author:

Dr. Tina Anand

Reader, Department

Pathology and Microbiology,

Homoeopathic Medical

College, Chandigarh

Punjab University,

Chandigarh, Punjab, India
- Children aged between eight and 13 years (Particularly boys)

- Middle aged men and women

- Women during pregnancy

- People who wear ill-fitted shoes or high heels etc. 


\section{Commonest causes of heel pain Plantar fasciitis}

It is the most common cause of chronic heel pain. The plantar fascia is a band of connective tissue that runs along the sole from the heel to the ball of the foot. One of its main roles is to keep the bones and joints in position. Bruising or overstretching of this ligament can cause inflammation and heel pain.

\section{Symptoms}

Plantar fasciitis typically causes a stabbing pain in or near the heel. The pain is usually the worst with the first few steps after awakening, although it can also be triggered by long periods of standing or when one gets up after sitting. The pain is usually worse after exercise, not during it.

\section{Physical examination}

A slight limp in walk may be present more so on standing from sitting position. Tenderness on medial aspect of heel. Reproducible pain on dorsiflexion of the foot with a reduced range of motion. Presence of a very high arch of foot.

\section{Investigations}

Diagnoses can be made on typical clinical history.

- X-Ray helps rule out spurs and other bone affections of heel.

- MRI though rarely advised, can show inflamed fascia, rupture or tear.

\section{Calcaneal spur}

A calcaneal spur is a form of bony exostosis i.e. a bony outgrowth of the calcaneal tuberosity formed either without any apparent cause or due to constant stress over the heel caused by ill-fitted shoes or high intensity exercises or in the obese. The spur impinges over the tendoachilles and other soft tissues causing pain. Though found in a high percentage of population as an X-Ray finding, it is not as commonly a cause of pain as there is also a large population with calcaneal spurs who remain asymptomatic throughout their life. It is thus important to rule out other causes of chronic heel pain in patients who have calcaneal spurs.

\section{Symptoms and examination}

Pain and tenderness, in symptomatic patients, usually on posterior aspect of heel.

\section{Investigation}

Spurs are easily visible on X-Rays (lateral).

\section{Sever's disease}

Sever's disease is the most common cause of heel pain in children aged eight to 16 . Sever's disease results from stress placed on the growth plate of the heel bone. An excessive amount of running or jumping causes inflammation of the growth plate, which results in pain. Rest, ice, stretching of the calf muscle and heel lifts are usually all that is required for recovery.

\section{Heel pad syndrome}

Heel pad syndrome is a condition that can develop due to changes in the thickness and elasticity of the heel pad. Heel pad is the thick elastic tissue formed of dense pockets of fat surrounded by tough elastic muscles fibres. It acts as a cushion distributing bodyweight, absorbing shock, protecting the underneath bones and ligaments during vigorous activities. Wear and tear of this pad leading to its thinning makes it incapable of absorbing shock and patient starts experiencing heel pain

\section{Symptoms/Examination}

Bruise like pain deep in the middle of the heel after running, jogging or standing for long duration. Mild cases may present with deep tenderness in the middle of the heel. On pressing deep into the middle of the heel, pain is reproduced.

\section{Investigations}

Atrophy or thinning of the fascia can be seen in MRI which is usually recommended in chronic and resistant cases of heel pain. Diagnoses can be made on a typical clinical history and physical examination.

\section{Achilles tendinopathy}

Overstretching, small tears, swelling of the Tendoachilles i.e. the tendon which joins our heel to the calf muscle can cause pain in the posterior aspect of the heel. It is a common cause of posterior heel pain in sports person and is referred to as Achilles tendinopathy.

\section{Examination}

Tenderness in posterior aspect of heel. Positive Thompson test in case of tear or rupture. In this test patient is made to lie on his abdomen with his feet hanging down the examination table. Squeezing the calf muscle of the affected foot should cause planter flexion of the foot. An abnormal planter flexion or absent planter flexion of foot indicates a torn or ruptured achilles tendon.

\section{Investigations}

MRI can show the tear or rupture or inflamed or swollen Achilles tendon and associated soft tissue.

\section{Calcaneal stress fracture}

Fracture of calcaneal bone is the second most common fracture caused due to stress. It causes pain in and around the heel.

\section{Investigation \\ Plain X-Ray}

\section{Haglund deformity}

Haglund's Deformity also known as "pump bump" is a bony enlargement on the back of heel causing irritation of tendoachilles and surrounding soft tissue leading to pain on posterior aspect of heel which worsens on rest or wearing ill-fitted shoes. The exact etiology is not known but could be hereditary,a tight Achilles tendon or a high arched foot. Women are more commonly affected and it is usually bilateral.

\section{Investigation}

It can be seen in simple X-Ray. 
Table 1: Differential diagnoses: Location of pain can be a guide to the proper diagnosis

\begin{tabular}{|c|c|c|c|c|c|}
\hline Condition & Planter fasciitis & Calcaneal spur & \begin{tabular}{|l|} 
Sever's disease \\
\end{tabular} & Heel pad syndrome & Calcaneal stress fracture \\
\hline Character of pain & $\begin{array}{l}\text {-Medial planter heel pain } \\
\text {-Aggravated in morning. } \\
\text { First few steps very } \\
\text { painful } \\
\text {-Worse after prolonged } \\
\text { periods of rest } \\
\text {-Worse prolonged } \\
\text { standing } \\
\text {-Better with movement }\end{array}$ & $\begin{array}{c}\text {-Medial planter heel pain } \\
\text {-Similar to planter } \\
\text { fasciitis } \\
\text {-Worse after ill-fitting } \\
\text { shoes } \\
\text {-Often misdiagnosed for } \\
\text { medial heel pain when } \\
\text { actual cause is planter } \\
\text { fasciitis }\end{array}$ & \begin{tabular}{|c|}
-Calcaneal \\
Apophysitis \\
-Pain in posterior \\
aspect of pain \\
-Negative \\
Thompson test
\end{tabular} & $\begin{array}{l}\text {-Deep bruise like pain in } \\
\text { middle of heel } \\
\text {-Worse after rest }\end{array}$ & $\begin{array}{c}\text {-Posterior heel pain } \\
\text {-Progressively worsening } \\
\text { pain following any activity } \\
\text {-Worsening on change to } \\
\text { harder walking surfaces }\end{array}$ \\
\hline
\end{tabular}

\begin{tabular}{|c|c|c|c|}
\hline Condition & Achillis tendinopathy & Haglund deformity & Nerve entrapment/neuromas \\
\hline Character of pain & $\begin{array}{c}\text {-Posterior heel pain } \\
\text {-Positive Thompson Test in case of } \\
\text { tendon tears or rupture }\end{array}$ & $\begin{array}{c}\text {-Posterior heel pain } \\
\text {-Aggravated on wearing low heel shoes which rub } \\
\text { against the protuberance }\end{array}$ & $\begin{array}{c}\text {-Pain accompanied with } \\
\text { tingling, numbness, burning } \\
\text { of friction of posterior aspect of heel of shoes }\end{array}$ \\
\hline
\end{tabular}

\section{Investigations}

1. Blood tests to rule out systemic diseases especially in bilateral affection of heels.

2. Blood tests for Arthropathies.

3. Simple X-Rays in cases of spurs and Haglund deformity.

4. MRI to diagnose soft tissue affections in seronegative patients with normal X-Rays where complaint is resistant to treatment or in patients with severe pain.

Though diagnosis is not required for prescribing homoeopathically yet it is important for associated conservative treatment/therapies and precautions to be suggested for early recovery.

\section{Conservative treatment and preventive measures}

Patients of chronic heel pain must follow the following:
- Rest from activities that stress the heel (such as running and jumping)/changing support

- Ice packs

- Regular foot massage, concentrating on the arch of the foot

- Associated Physiotherapy

- Professional strapping

- A splint worn at night

- Flexibility exercises

- Ultrasound therapy

- Checking your posture and walking style, to correct imbalances and gait abnormalities that may contribute to the pain

- Shoe inserts (orthoses) to help support the foot in some cases. Surgery may be recommended to treat conditions including neuroma, bursitis and heel spur

Table 2: Homoeopathic approach: Medicines are selected based on individual symptoms

\begin{tabular}{|c|c|c|c|c|c|}
\hline Chapter & Rubric & Subrubric & Grade I & Grade II & Grade III \\
\hline Feet & $\begin{array}{c}\text { Pain, heels } \\
\text { (general) }\end{array}$ & & RHOD, PULS. & $\begin{array}{c}\text { Am-m, Cal., Carb-an., Coloc., Kali-iod., } \\
\text { Nat-c., Petr., Rhus-t., Valer., Zinc. }\end{array}$ & \\
\hline & & -bone & & & $\begin{array}{l}\text { Berb., caps., coloc, } \\
\text { crot. hor., ign }\end{array}$ \\
\hline & & -evening & PULS. & Nat. carb. & Amm. mur., Zinc. \\
\hline & & -gouty & & & $\begin{array}{l}\text { Calc., kali-iod., lyco., } \\
\text { meph., sabin }\end{array}$ \\
\hline & & $\begin{array}{l}\text {-morning } \\
\text { first step } \\
\text { waking }\end{array}$ & & $\begin{array}{c}\text { Amn. carb., } \\
\text { Rhus. tox } \\
\text { Amn. carb., ars }\end{array}$ & \\
\hline & & -nails like under the skin & & Rhus-t & \\
\hline & & $\begin{array}{l}\text {-night } \\
3 \text { a.m. }\end{array}$ & & $\begin{array}{l}\text { Am-m. } \\
\text { Am-m. }\end{array}$ & \\
\hline & & -pulsating & & Nat-carb & \\
\hline & & -rheumatic & RHOD. & & \\
\hline & & -Right & & Am-m. & \\
\hline & & -sitting & VALER. & & \\
\hline & & -splinter as if & & Petr., Rhus-t. & Sulph \\
\hline & & -stone as from & & & Lyco. \\
\hline & & $\begin{array}{c}\text {-tendons of the foot after } \\
\text { walking }\end{array}$ & & & Sulph. \\
\hline & & -ulcerative & & -Am-m., Caust., Kali-iod., Nt-sulph., Zinc. & \\
\hline & & -walking & & Ars., Caust., Zinc & \\
\hline & & -walking amelioration & VALER. & & \\
\hline & & -wine afetr & ZINC. & & \\
\hline
\end{tabular}

- Flexibility exercises

- Ultrasound therapy
- Checking your posture and walking style, to correct imbalances and gait abnormalities that may contribute 
to the pain

- Shoe inserts (orthoses) to help support the foot in some cases. Surgery may be recommended to treat conditions including neuroma, bursitis and heel spur

Table 3: Rubrics selected for heel pain: Murphy's repertory

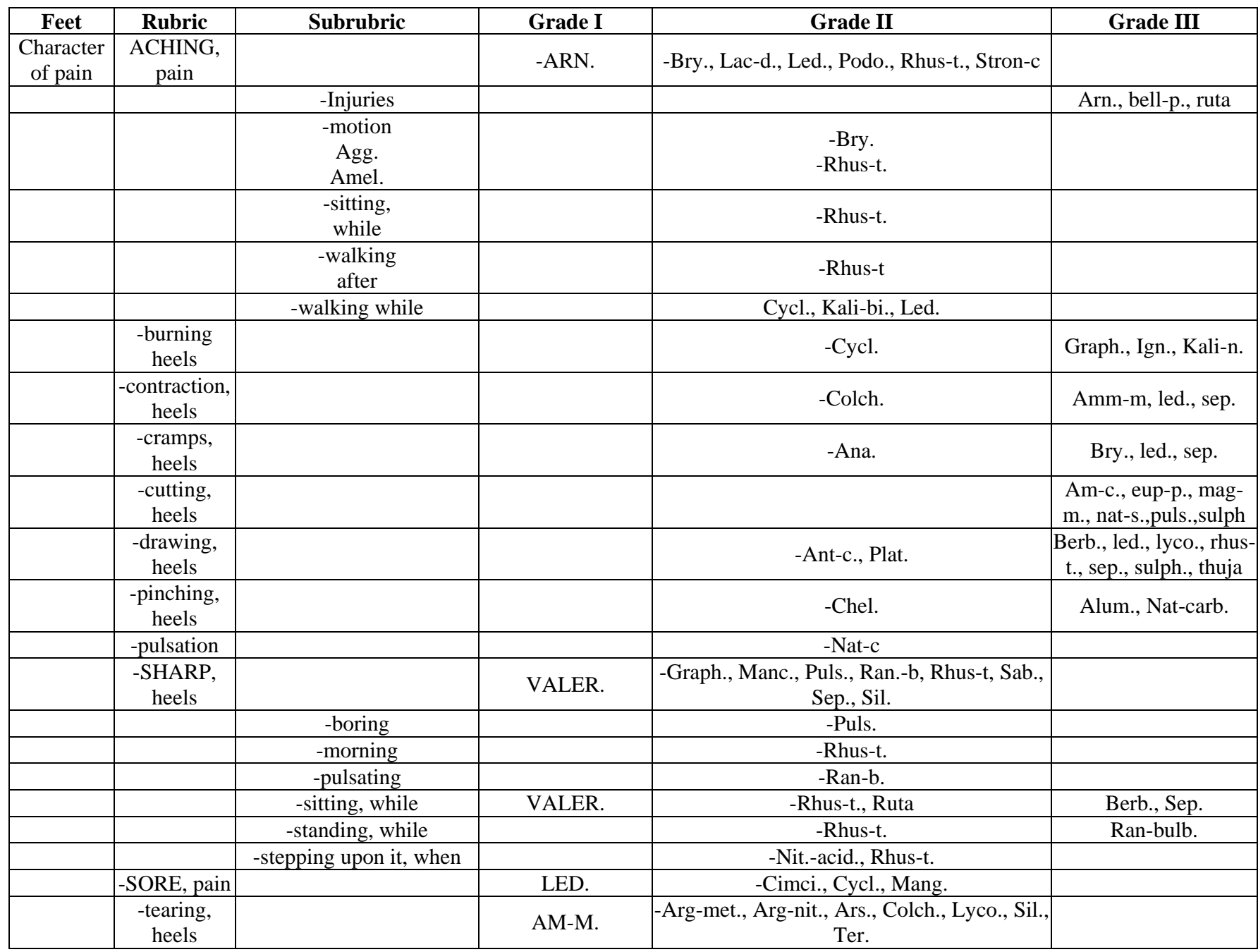

Table 4: Rubrics for achilles tendinopathy from Murphy's repertory

\begin{tabular}{|c|c|c|c|c|c|}
\hline Chapter & Rubric & Subrubric & Grade I & Grade II & Grade III \\
\hline Ankles & $\begin{array}{l}\text { Achilles } \\
\text { tendons }\end{array}$ & & & $\begin{array}{l}\text {-Calc., Calen., } \\
\text { Merc., Rhus t., Ruta, Zinc. }\end{array}$ & $\begin{array}{l}\text { Aur-met., bry., cimci., } \\
\text { rhod., thuja }\end{array}$ \\
\hline & & -achining pain & & -Cimci. & \\
\hline & & -boring pain & & & Aur-mur-nat. \\
\hline & & $\begin{array}{c}-\begin{array}{c}\text {-contraction of muscles and } \\
\text { tendons }\end{array} \\
\end{array}$ & & $\begin{array}{c}\text {-Calc., Cann-s., Carb. an., colch., Graph., } \\
\text { Kali-carb., Sep., }\end{array}$ & $\begin{array}{l}\text { Acon., cimci., } \\
\text { Ruta., zinc } \\
\end{array}$ \\
\hline & & \begin{tabular}{|c|}
-cramps \\
night in bed
\end{tabular} & & Calc., Caust. Caust. & Calc. \\
\hline & & $\begin{array}{l}\text {-drawing pain } \\
\text { motionamel. } \\
\text { Walking fast } \\
\end{array}$ & VALER. & $\begin{array}{c}\text {-Calc., Carb-an., Kali-bi., Zinc } \\
\text {-thuja }\end{array}$ & $\begin{array}{l}\text {-Aesc., berb., nat- } \\
\text { mur., thuja }\end{array}$ \\
\hline & & -inflammation & & -Sep., Zinc & -ruta \\
\hline & & -injuries to & & -Calen. & -ruta \\
\hline & & $\begin{array}{c}\text {-pain } \\
\text { Exertion on } \\
\text { Morning } \\
\text { Night } \\
\text { Rheumatic } \\
\text { Stairs when going up } \\
\text { Standing } \\
\text { Walking while } \\
\text { Walking amel. }\end{array}$ & & $\begin{array}{c}\text {-Calc., Carb-an., Cann-sat., Cinn., Colch., } \\
\text { Kali-bi., led., merc., zinc } \\
\text {-Ign. }\end{array}$ & $\begin{array}{c}\text { Aes., bernz-ac., berb., } \\
\text { bry., } \\
\text { Calen., cimic., } \\
\text { Ing., rhod., ruta., } \\
\text { Thuja } \\
\text {-sulph } \\
\text {-muratic acid } \\
\text {-bry., cimci } \\
\text {-rhus. t. } \\
\text {-benz.ac., berb. }\end{array}$ \\
\hline
\end{tabular}




\begin{tabular}{|l|l|l|l|l|l|}
\hline & & & & -Kali-b-., Rhod., Rhus-t & -bry. Cinn., ign. \\
\hline & & -pulsation & & & -zinc \\
\hline & & -sore pain & & -Aes., bry., cimci. & \\
\hline & & -swelling & & $\begin{array}{c}\text {-alum., calc., caust., } \\
\text { colch., ing., kali-bi., zinc }\end{array}$ & -Bell., berb., thuj \\
\hline & & -tearing pain & & -caust., sep., zinc. & \\
\hline
\end{tabular}

Though cases need to be treated individually still based on the most frequently presented symptoms of heel pain following medicines cover the relevant rubrics - Valeriana, Rhododendron, Zincum Metallicum, Thuja Occidentalis, Pulsatilla, Ruta, Ledum, Colchicum, Amm-Mur, Cimcifuga, Ignatia, Calendula, Arnica.

Homoeopathic indicated medicine along with correct conservative treatment, necessary precautions and exercises will help patient recover earlier.

\section{References}

1. Why do my heels hurt and what can I do about it? Written by Yvette Brazier on 5/02/2018 at www.medicalnewstoday.com (Internet)

2. Heel pain at www.orthoinfo.aaos.org (Internet)

3. What causes heel pain- Written by Darla Burke updated on March 7, 2019 at www.healthline.com

4. Heel pain causes at www.mayoclinic.org

5. Murphy's Repertory

6. Diagnosis of Heel pain; by Priscilla Tu DO; Jeffery R Bytomski, DO; Duke University, Durham, North Carolina: American Family Physician 2011;84(8):909916.

7. Diagnosis of Heel pain in Adults: American Family Physician. By Trau Aldringe MD, Southern Illinois University School of medicine, Springfield, Illinois.

8. Mark Wolgin MD, Charles Cook MD, Charles Graham MD. Conservative treatment of Planter Heel pain: Long-Term Follow Up. journals.sagepub.com.

9. Mc Poil TG, Martin RRL, Cornwall MW. Heel painPlanter Fasciitis. jospt.org

10. Stephen 1, Barrett DPM, Robert Malley, DPM O, Reddy SR. Planter Fasciitis and other causes of Heel Pain. Effect of homoeopathic medicine Lycopodium clavatum in urinary calculi. International Journal of Applied Research 2017;3(1):790-791.

11. Stefano Salvoli, Maddalena Guidi, Giulia Marcotulli. The Effectiveness Of Conservative Non Pharmacological treatment of Planter Heel Pain; A Systematic Review with Meta-analysis. The Foot 2017;33:57-67. Elsveir

12. Crawford F, Snaith M. How Effective is therapeutic ultrasound in treatment of Heel Pain. Annals of The Rheumatic Diseases 1996. ard.bmj.com

13. Young B, Walker MJ, Strunce J, Boyler R. A Combined Treatment Approach Emphasizing Impairement based Mannual Physical Therapy for Planter Heel Pain: a Case Series. jospt.org

14. Justin Sullivan PT, MHlthSc Joshua Burns, Roger Adams. Musculoskeletal and Activity Related Factors associated with Planter Heel pain. Foot and Ankle International- Sage Journals 2015;36(1).

15. Rio E, Mayers S, J Cook. Heel Pain - a Practical Approach. Australian Family Physician 2015. search information.org 